Original Research Paper

\title{
Environmental Risk Assessment of Coal-Ash-Amended Soil Based on Continuous Planting of Pakchoi
}

\author{
${ }^{1}$ Wenxuan Sun, ${ }^{1}$ Liyong Bai, ${ }^{1}$ Huihui Ji, ${ }^{2}$ Wentao Huo, ${ }^{3 *}$ Zhen Huang, ${ }^{1}$ Kezhong Liu and ${ }^{1 *}$ Dongyun Yan \\ ${ }^{1}$ College of Environmental Science and Engineering, Qingdao University, Qingdao 266071, China \\ ${ }^{2}$ The First Company of China Eighth Engineering Bureau, Jinan 250014, China \\ ${ }^{3}$ School of Chemistry and Chemical Engineering, Qingdao University, Qingdao 266071, China
}

\author{
Article history \\ Received: 15-03-2021 \\ Revised: 20-04-2021 \\ Accepted: 26-04-2021 \\ Corresponding Author: \\ Zhen Huang \\ School of Chemistry and \\ Chemical Engineering, \\ Qingdao University, Qingdao \\ 266071, China \\ Email:1006432906@qq.com \\ Dongyun Yan \\ College of Environmental \\ Science and Engineering, \\ Qingdao University, Qingdao \\ 266071, China \\ Email: yandongyun666@hotmail.com
}

\begin{abstract}
The agricultural application of coal ash which contains a variety of chemical nutrients may also cause heavy metal pollution of crops and soil. In this study, pakchoi was cultivated for four consecutive seasons in pots of brown soil amended with fly ash or bottom ash. With subsequent plantings, the total concentrations in the four fractions of $\mathrm{Pb}$, $\mathrm{Cr}$ and $\mathrm{Cu}$ decreased, while the concentrations of $\mathrm{Pb}, \mathrm{Cr}$ and $\mathrm{Zn}$ dissolved in acetic acid increased. The lowest fresh weight of pakchoi were seen when $15 \%$ fly ash was applied. The edible parts of pakchoi contained more heavy metals than the roots. Calculating the Nemerow Pollution Index (NPI) according to the Environmental Protection Standards, the risk of heavy metals in coal ash-amended soils was low. With subsequent plantings, the Risk Assessment Code (RAC) of $\mathrm{Pb}, \mathrm{Cr}$ and $\mathrm{Zn}$ increased gradually and $\mathrm{Zn}$ eventually reached a medium level. The study confirmed that coal ash had phytotoxic effects on pakchoi and application of coal ash confered a risk of soil pollution.
\end{abstract}

Keywords: Bottom Ash, Environmental Risk Assessment, Fly Ash, Pakchoi, Heavy Metal

\section{Introduction}

The annual worldwide output of coal ash reached about 600 million tons in 2010 (Ahmaruzzaman, 2010). There are two main types of coal ash: Fly ash, comprising particles in the range of $1-100 \mu \mathrm{m}$, which can be discharged with flue gas and collected by electrostatic precipitators, accounts for $75-80 \%$ of the total ash (Ahmaruzzaman, 2010; Shi et al., 2003; Qunhu et al., 2008) and bottom ash, with particles of 100-10,000 $\mu \mathrm{m}$, accounts for $13-20 \%$ of the total ash. Bottom ash usually remains at the bottom of the coal-fired boiler after combustion (Mukhtar et al., 2003).

Coal ash has attracted much attention as a soil amendment because it is rich in trace elements. It was found that fly ash can improve the physicochemical properties of soil, such as $\mathrm{pH}$, water-holding capacity and conductivity (El-Mogazi et al., 1998; Phung et al., 1979; Sarkar et al., 2017; Siddiqui et al., 2004). However, fly ash contains elements that cause metal toxicity in plants, such as Arsenic (As), Cadmium (Cd), Lead (Pb), Mercury (Hg) and Chromium (Cr) (Gupta et al., 2002; Pandey and Singh,
2020). In addition, trace elements such as Copper $(\mathrm{Cu})$, Zinc ( $\mathrm{Zn}), \mathrm{As}, \mathrm{Pb}$ and soon were detected at trace levels in rice grains produced in fly-ash-treated soil, but they did not exceed the critical levels for plant growth (Patra et al., 2012). Another research showed that the addition of fly ash reduced the bioavailability of heavy metals in acidic soils polluted by steel slag (Hao et al., 2012). The risk associated with long-term application of fly ash to soil-plant systems is an important research topic and long-term experiments have examined remediation of contaminated soil by fly ash. For example, after an 8-year field experiment, the concentrations of $\mathrm{Cd}, \mathrm{Pb}$ and $\mathrm{Zn}$ extracted from polluted soil restored by fly-ash-aided plant remediation were lower than those extracted from untreated soil (Lopareva-Pohu et al., 2011a). However, few studies have evaluated crop biomass or the heavy-metal contents of plants or soil after continuous use of coal ash. In addition, few studies have examined differences in the agricultural use of bottom and fly ash.

The negative impact of coal ash on the environment is multifaceted, affecting land use, particle flow and 
heavy-metal and radioactive-material pollution and soon (Jala and Goyal, 2006; Li and Jiang, 1998). When coal ash is applied to soil, the heavy metals are retained in the leaching solution during migration, which leads to soil pollution and adverse effects on plants and human health. Therefore, it is important to study whether coal ash is sufficiently safe to be applied to soil and to assess the risks associated with the presence of heavy metals in soil after coal ash application.

This study analyzed the heavy-metal content and $\mathrm{pH}$ of coal-ash-amended soil after four consecutive plantings of pakchoi. Differences in the agricultural effects of fly and bottom ash were analyzed using three evaluation methods, to evaluate the general contamination characteristics of metals in coal-ashamended soil. Based on the results, the safety of coal ash for agricultural use is discussed.

\section{Materials and Methods}

\section{Coal-Ash Treatments}

The coal ash used in this experiment was provided by Yancon Group, a coal chemical enterprise in Shandong Province, China. The types of coal ash were divided into bottom ash (8-100 mesh) and fly ash (100-200 mesh), which have different physicochemical properties (Table 1). Bottom ash is collected at the bottom of an industrial boiler furnace because of its large particle size, while fly ash is present in flue gas dust and is collected in a bag filter. The test soil was collected at depths of 0-20 cm from farmland in Laixi District, Qingdao, Shandong Province (Table 1). The coal ash and field soil were air-dried. The soil was passed through a $2-\mathrm{mm}$ sieve and mixed with fly ash in five proportions (by weight): Blankcontrol (CK), 0\% ash-100\% soil; BA5, 5\% bottom ash-95\% soil; BA15, $15 \%$ bottom ash-85\% soil; FA5, 5\% fly ash-95\% soil; and FA15, $15 \%$ fly ash- $85 \%$ soil.

\section{Pots Experiment}

20-cm-diameter and 17-cm-high plastic pots that had no holes at the bottom were filled with $5 \mathrm{~kg}$ of a coal ash soil mixture. Each pot was sown with 10 pakchoi seeds (Brassica chinensis L.). All pots were irrigated with tap water instead of natural precipitation and were placed in a net room. After the true leaves appeared, two seedlings of similar size were left in each pot. Each treatment was replicated five times and three plants with similar growth were analyzed. After harvesting, the soil was air-dried and re-mixed and pakchoi were planted again. The plants were cultivated from July 1, 2016 to July 22, 2016 for the first time (t1), from August 26, 2016 to September 19, 2016 for the second time (t2), from September 27, 2016 to
November 23, 2016 for the third time (t3) and from April 17, 2017 to June 4, 2017 for the fourth time (t4).

\section{Collection of Soil and Plant Sample}

The harvested plants were first washed with tap water and then with distilled water. The roots and shoots were separated and weighed. The plant samples were put in an oven at $105^{\circ} \mathrm{C}$ for $30 \mathrm{~min}$ and then dried to a constant weight $(24 \mathrm{~h})$ in an oven at $70^{\circ} \mathrm{C}$. The plant samples were powdered and screened through a 50-mesh sieve. The first batch of pakchoi was not analyzed chemically because of its insufficient biomass. Coal ash-soil samples were collected five times: Once before planting and four times after harvesting and labeled T0, T1, T2, T3 and T4, respectively. The soil samples were naturally air-dried, ground and stored.

\section{Chemical Analysis of Plant and Soil Sample}

The three-step extraction method proposed by the European Community Bureau of Reference (BCR) was used to extract four fractions of heavy metals in the coal ash-soil samples (Feng et al., 2009; Zhang et al., 2010): The acetic-acid-soluble, reducible, oxidizable and residual fractions. To digest the residue, it was placed in a crucible, dried for $2 \mathrm{~h}$ in an oven at $100^{\circ} \mathrm{C}$, weighted after drying and then stored in a muffle oven at $600^{\circ} \mathrm{C}$ for $5 \mathrm{~h}$. The treated residue was weighted to $0.2 \mathrm{~g}$ and put in a Polytetrafluoroethylene (PTFE) crucible and digested by triacid method $\left(\mathrm{HNO}_{3}: \mathrm{HF}: \mathrm{HClO}_{4}=5: 5: 8\right)$. The concentrations of $\mathrm{Pb}, \mathrm{Cr}, \mathrm{Cu}$ and $\mathrm{Zn}$ in treatment solution were determined by ICP-OES. The recovery rates of standard samples of $\mathrm{Pb}, \mathrm{Cr}, \mathrm{Cu}$ and $\mathrm{Zn}$ were 97.52, 90.97, 94.20 and $95.63 \%$, respectively. The total heavymetal concentration was the sum concentration of the four fractions of the individual metals and the extractable content was the sum of the contents of the acetic-acid-soluble, reducible and oxidizable forms.

$0.4 \mathrm{~g}$ samples were weighted and digested in the PTFE crucible with triacid digestion $\left(\mathrm{HNO}_{3}: \mathrm{HClO}_{4}=\right.$ 4:1 and a few drop of $\mathrm{HF}$ ). The concentrations of $\mathrm{Pb}, \mathrm{Cr}$, $\mathrm{Cu}$ and $\mathrm{Zn}$ in treatment solution were determined by ICP-OES. The standard recoveries of $\mathrm{Pb}, \mathrm{Cr}, \mathrm{Cu}$ and $\mathrm{Zn}$ in the plant samples were 94.50, 101.87, 91.72 and $88.77 \%$, respectively.

The $\mathrm{pH}$ of the coal ash-soil mixtures was determined in 1:2.5 soil:distilled water suspension (Okalebo et al., 2002).

\section{Risk Assessment Methodology}

Single-factor index $\left(P_{i}\right)$, Nemerow Pollution Index (NPI) (Song et al., 2017), Potential Ecological Risk Index (PERI) (Ke et al., 2017) and Risk Assessment Code (RAC) (Sundaray et al., 2011) were used to analyse the pollution risk of heavy-metals to soil environment. The detailed formulas were presented as followed and the risk classification was presented in the Table 2. 
Table 1: Basic physicochemical properties of the tested soil and coal ash

\begin{tabular}{|c|c|c|c|c|c|c|c|}
\hline Parameters & Bottom ash & Fly ash & Soil & Risk & values ( & $618-2018$ & \\
\hline Particle size (mesh) & 8 to 100 & 100 to 200 & - & - & - & - & - \\
\hline Sand $(\%)$ & - & - & 46.7 & - & - & - & - \\
\hline Silt $(\%)$ & - & - & 42.4 & - & - & - & - \\
\hline Clay $(\%)$ & - & - & 11.0 & - & - & - & - \\
\hline $\mathrm{pH}$ & 12.4 & 12.6 & 6.08 & $\leqq 5.5$ & $5.5 \sim 6.5$ & $6.5 \sim 7.5$ & $>7.5$ \\
\hline $\operatorname{SOM}\left(\mathrm{g} \mathrm{kg}^{-1}\right)$ & - & - & 8.91 & - & - & - & - \\
\hline $\mathrm{AP}\left(\mathrm{g} \mathrm{kg}^{-1}\right)$ & - & - & 7.49 & - & - & - & - \\
\hline $\mathrm{AK}\left(\mathrm{g} \mathrm{kg}^{-1}\right)$ & - & - & 6.63 & - & - & - & - \\
\hline $\mathrm{Cu}\left(\mathrm{mg} \mathrm{kg}^{-1}\right)$ & 64.7 & 106 & 44.0 & 50 & 50 & 100 & 100 \\
\hline $\mathrm{Pb}\left(\mathrm{mg} \mathrm{kg}^{-1}\right)$ & 149 & 167 & 69.9 & 70 & 90 & 120 & 170 \\
\hline $\mathrm{Cr}\left(\mathrm{mg} \mathrm{kg}^{-1}\right)$ & 95.3 & 64.8 & 46.5 & 150 & 150 & 200 & 250 \\
\hline $\mathrm{Zn}\left(\mathrm{mg} \mathrm{kg}^{-1}\right)$ & 71.5 & 55.9 & 98.0 & 200 & 200 & 250 & 300 \\
\hline
\end{tabular}

Note: SOM, AP and AK represents organic matter, available phosphorus and available potassium of soils

Table 2: Classification of the evaluation index and the pollution levels

\begin{tabular}{|c|c|c|c|}
\hline Evaluation index & Evaluation values & & Pollution degree \\
\hline \multirow[t]{6}{*}{ NPI } & $P_{i} \leq 1$ & $\mathrm{NPI} \leq 0.7$ & No risk \\
\hline & $1 \leq P_{i} \leq 2$ & $0.7<\mathrm{NPI} \leq 1$ & Low risk \\
\hline & $2 \leq P_{i} \leq 3$ & $1<\mathrm{NPI} \leq \overline{2}$ & Medium risk \\
\hline & $P_{i}>3$ & $2<\mathrm{NPI} \leq 3$ & High risk \\
\hline & $E_{f}^{i_{f}}<40$ & $\mathrm{RI}<150$ & Low risk \\
\hline & $40 \leq E_{f}^{i}<80$ & $150 \leq \mathrm{RI}<300$ & Moderate risk \\
\hline \multirow[t]{3}{*}{ PERI } & $80 \leq E_{f}^{i_{f}}<160$ & $300 \leq \mathrm{RI}<600$ & Considerable risk \\
\hline & $160 \leq E_{f}^{i}<320$ & $\mathrm{RI} \geq 600$ & High risk \\
\hline & $E_{f}^{i_{f}} \geq 320$ & & Very high risk \\
\hline \multirow[t]{5}{*}{ RAC } & $\mathrm{RAC} \leq 1$ & & No risk \\
\hline & $1<\mathrm{RAC} \leq 10$ & & Low risk \\
\hline & $10<\mathrm{RAC} \leq 30$ & & Moderate risk \\
\hline & $30<\mathrm{RAC} \leq 50$ & & High risk \\
\hline & $\mathrm{RAC}>50$ & & Very high risk \\
\hline
\end{tabular}

Single-factor index $\left(P_{i}\right)$ was used to assess the degree of risk of a given element in soil and calculated using the following Equation:

$P_{i}=C_{i} / S_{i}$

where, $C_{\mathrm{i}}$ is the total content of the heavy metal in coalash-amended soil $\left(\mathrm{mg} \mathrm{kg}^{-1}\right)$ and $S_{i}$ is the content of the same metal in the Soil Environmental Quality Standards (Table 2), or the reference value in the Environmental Quality Evaluation Standards for Edible Agricultural Products (HJ/T332-2006, China).

The Nemerow Pollution Index (NPI) was calculated as follows:

$N P I=\sqrt{\frac{\bar{P}_{i}^{2}+P_{i \max }^{2}}{2}}$

where, $P_{\mathrm{i}}$ and $P_{\mathrm{imax}}$ are the mean and maximum values of the single factor indices $\left(P_{\mathrm{i}}\right)$ for a given heavy metal in coal-ash-amended soil, respectively. The risk classification were categorized into four levels (Table 2).

The Potential Ecological Risk Index (PERI) of a given metal $\left(E_{f}^{i}\right)$ in fly-ash-amended soil is defined as:
$E_{f}^{i}=T_{f}^{i} \times C^{i} / C_{0}^{i}$

The results were used to calculate the PERI of the sampling sites, as follows:

PERI $=\sum_{i=1}^{n} E_{f}^{i}$

where, $C_{\mathrm{i}}$ is the concentration of metal $i$ in soil amended with coal ash; $C_{0}$ is the concentration of this metal in soil without coal ash; $T_{f}^{i}$ is the biological toxicity factor of an individual element, which was determined for $\mathrm{Zn}=1<$ $\mathrm{Cr}=2<\mathrm{Cu}=\mathrm{Pb}=5$. The risk classification is presented in Table 2.

The Risk Assessment Code (RAC) is used to assess the biological risk and mobility of the acetic-acid-soluble form of heavy metals. The formula is as follows:

$R A C=C_{e}^{i} / C_{t}^{i}$

where, the $C_{e}^{i}$ is the concentration of the acetic-acid extractable fraction of heavy metal $i$ and $C_{t}^{i}$ is the total content of heavy metal $i$ in the four fractions. A five 
level risk classification has been categorized in terms of RAC (Table 2).

\section{Statistical Analysis}

All experimental values are the means of three replicates per treatment with Standard Deviation (SD). Statistical analyses of different treatments in the same batch were performed by ANOVA analysis and Duncan's multiple range tests $(P<0.05)$ by SPSS software (version 19.0). Correlations among the heavy-metal contents of the experimental soils, the heavy-metal contents and fresh weight of the experimental pakchoi and the $\mathrm{pH}$ value of experimental soils were calculated by the "cor" function in the package of $\mathrm{R}$ and the graph was constructed by the Performance Analytics" function and "corrplot" function.

\section{Results and Discussion}

\section{Concentrations of Heavy Metals in Coal- Ashamended Soil}

Before planting pakchoi, the total concentrations of the four fractions of heavy metals in the $\mathrm{CK}$ was in the order $\mathrm{Zn}>\mathrm{Pb}>\mathrm{Cr}>\mathrm{Cu}$ and the total concentrations of the four fractions of the heavy metals in the coal-ash-amended soil was also in the same order but the concentration of all elements increased significantly (Fig. 1). Except $\mathrm{Cu}$, the order of the total concentrations of $\mathrm{Zn}, \mathrm{Pb}, \mathrm{Cr}$ was similar to the result reported by (Nayak et al., 2015).
With subsequent plantings of pakchoi, the total $\mathrm{Pb}$, $\mathrm{Cr}$ and $\mathrm{Cu}$ concentrations in the four fractions in the $\mathrm{CK}$ were relatively stable, while the total $\mathrm{Pb}$ and $\mathrm{Cr}$ concentrations in the coal-ash-amended soil decreased gradually. The total $\mathrm{Cu}$ concentrations were higher in fly-ash-amended soil than in bottom-ash-amended soil, likely because the $\mathrm{Cu}$ content of fly ash was higher than that of bottom ash and the $\mathrm{Cu}$ dissolved more readily in fly-ash-amended soil. Zn showed different changes. Except for BA5, the total $\mathrm{Zn}$ concentrations of the four fractions in the other treatments changed little with subsequent plantings and even increased slightly.

\section{Concentrations of Acetic-Acid-Extractable Heavy Metals in Coal-Ash-Amended Soil}

The bioavailability or potential ecological risks cannot be characterized using only the total concentration of theheavy metal in the four fractions (Maiti and Jaiswal, 2008). The acetic-acid-extractable concentrations of the heavy metals did not exceed $15 \%$ of the total content (Fig. 1 ), but played a key role in crop uptake. Before planting pakchoi, the acetic-acid-extractable concentrations of heavy metals in $\mathrm{CK}$ were in the order $\mathrm{Cu}>\mathrm{Pb}>\mathrm{Zn}>\mathrm{Cr}$ (Table 3). The order of total concentrations differed from that of the acetic-acid-extractable heavy metals. For example, the total $\mathrm{Cu}$ content was lowest, but the aceticacid- extractable $\mathrm{Cu}$ content was highest, indicating that different metals have different degrees of activation.

Table 3: The acetic-acid-extractable concentration of heavy metals in the soil under different coal-ash treatments and pakchoi plantings $\left(\mathrm{mg} \mathrm{kg}^{-1}\right)$ (Bai et al., 2019)

\begin{tabular}{|c|c|c|c|c|c|c|}
\hline Elements & Soil batches & $\mathrm{CK}$ & BA5 & BA15 & FA5 & FA15 \\
\hline \multirow[t]{5}{*}{$\mathrm{Pb}$} & $\mathrm{T} 1$ & $1.52 \mathrm{c}$ & $1.73 \mathrm{e}$ & $2.15 \mathrm{~d}$ & $1.61 \mathrm{e}$ & $1.82 \mathrm{e}$ \\
\hline & $\mathrm{T} 2$ & $1.62 \mathrm{ab}$ & $1.87 \mathrm{~d}$ & $2.23 c$ & $1.74 \mathrm{~d}$ & $1.90 \mathrm{~d}$ \\
\hline & $\mathrm{T} 3$ & $1.57 \mathrm{bc}$ & $1.93 \mathrm{c}$ & $2.37 \mathrm{~b}$ & $1.87 \mathrm{c}$ & $1.98 \mathrm{c}$ \\
\hline & $\mathrm{T} 4$ & $1.66 \mathrm{a}$ & $2.05 \mathrm{~b}$ & $2.39 \mathrm{~b}$ & $1.96 \mathrm{~b}$ & $2.13 b$ \\
\hline & $\mathrm{T} 5$ & $1.65 \mathrm{a}$ & $2.16 \mathrm{a}$ & $2.57 \mathrm{a}$ & $2.36 \mathrm{a}$ & $2.45 \mathrm{a}$ \\
\hline \multirow[t]{5}{*}{$\mathrm{Cr}$} & $\mathrm{T} 1$ & $0.52 \mathrm{c}$ & $0.63 d$ & $0.80 \mathrm{~d}$ & $0.61 \mathrm{~d}$ & $0.82 \mathrm{~d}$ \\
\hline & $\mathrm{T} 2$ & $0.53 \mathrm{c}$ & $0.86 \mathrm{~d}$ & $0.94 d$ & $0.74 \mathrm{~d}$ & $0.90 \mathrm{~d}$ \\
\hline & $\mathrm{T} 3$ & $0.56 b c$ & $0.93 c$ & $1.07 \mathrm{c}$ & $0.87 \mathrm{c}$ & $0.92 \mathrm{c}$ \\
\hline & $\mathrm{T} 4$ & $0.60 \mathrm{ab}$ & $1.15 b$ & $1.56 \mathrm{~b}$ & $0.96 b$ & $1.39 \mathrm{~b}$ \\
\hline & $\mathrm{T} 5$ & $0.65 \mathrm{a}$ & $1.38 \mathrm{a}$ & $1.79 \mathrm{a}$ & $1.36 \mathrm{a}$ & $1.52 \mathrm{a}$ \\
\hline \multirow[t]{5}{*}{$\mathrm{Cu}$} & $\mathrm{T} 1$ & $5.88 \mathrm{c}$ & $7.06 \mathrm{a}$ & $7.49 \mathrm{a}$ & $6.80 \mathrm{a}$ & $7.56 \mathrm{a}$ \\
\hline & $\mathrm{T} 2$ & $5.77 \mathrm{bc}$ & $6.36 \mathrm{~b}$ & $7.07 \mathrm{~b}$ & $6.05 b$ & $6.97 b$ \\
\hline & $\mathrm{T} 3$ & $5.71 \mathrm{c}$ & $5.68 \mathrm{c}$ & $6.37 c$ & $5.33 c$ & $6.98 b$ \\
\hline & $\mathrm{T} 4$ & $6.06 a b$ & $5.63 c$ & $6.06 \mathrm{~d}$ & $5.05 \mathrm{~d}$ & $6.37 \mathrm{c}$ \\
\hline & T5 & $6.19 \mathrm{a}$ & $4.70 \mathrm{~d}$ & $5.71 \mathrm{e}$ & $4.64 \mathrm{e}$ & $5.98 \mathrm{~d}$ \\
\hline \multirow[t]{5}{*}{$\mathrm{Zn}$} & $\mathrm{T} 1$ & $0.89 \mathrm{c}$ & $1.46 \mathrm{e}$ & $1.66 \mathrm{~d}$ & $1.79 \mathrm{~d}$ & $1.97 \mathrm{~d}$ \\
\hline & $\mathrm{T} 2$ & $0.54 \mathrm{~d}$ & $1.81 \mathrm{~d}$ & $2.35 \mathrm{c}$ & $2.07 \mathrm{~d}$ & $2.47 \mathrm{c}$ \\
\hline & $\mathrm{T} 3$ & $0.74 \mathrm{c}$ & $2.30 \mathrm{c}$ & $2.57 \mathrm{c}$ & $2.87 \mathrm{c}$ & $2.63 \mathrm{c}$ \\
\hline & $\mathrm{T} 4$ & $2.50 \mathrm{~b}$ & $4.44 b$ & $6.10 \mathrm{~b}$ & $8.82 b$ & $4.75 b$ \\
\hline & $\mathrm{T} 5$ & $8.16 \mathrm{a}$ & $13.23 \mathrm{a}$ & $11.9 \mathrm{a}$ & $14.9 \mathrm{a}$ & $14.4 \mathrm{a}$ \\
\hline
\end{tabular}

Note: T1, soil before planting the first batch of pakchoi; T2, soil before planting the second batch; T3, soil before planting the third batch; T4, soil before planting the fourth batch; T5, soil after planting the fifth batch. CK, $0 \%$ ash-100\% soil; BA5, 5\% bottom ash95\% soil; BA15, 15\% bottom ash-85\% soil; FA5, 5\% fly ash-95\% soil; and FA15, 15\% fly ash-85\% soil. The different letters indicate significant difference among treatment at $P<0.05$ (Duncan' s multiple range test) 

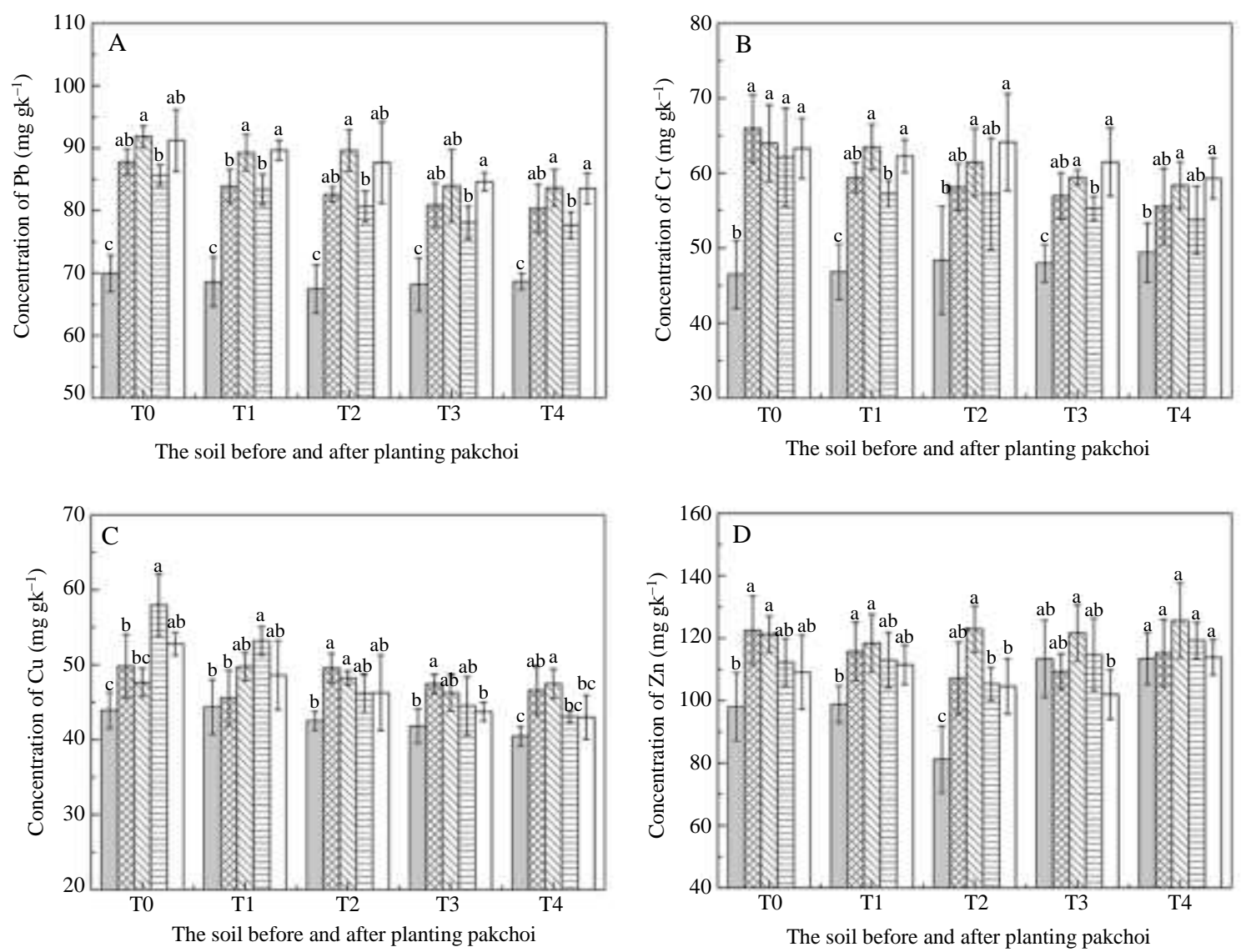

CK
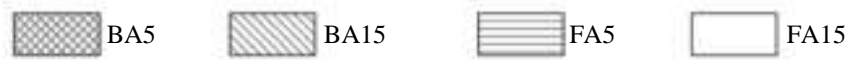

Fig. 1: Effects of different coal-ash treatments and pakchoi plantings on the heavy-metal content of soil; Note: T0, soil before planting the first batch of pakchoi; T1, soil before planting the second batch; T2, soil before planting the third batch; T3, soil before planting the fourth batch; T4, soil after planting the fifth batch. CK, $0 \%$ ash-100\% soil; BA5, 5\% bottom ash- 95\% soil; BA15, $15 \%$ bottom ash- $85 \%$ soil; FA5, 5\% fly ash-95\% soil; and FA15, 15\% fly ash-85\% soil. The different letters indicate significant difference among treatment at $P<0.05$ (Duncan's multiple range test). The same meanings are as follow

The acetic-acid-extractable concentrations of $\mathrm{Pb}, \mathrm{Cr}$ and $\mathrm{Zn}$ in pakchoi increased with the plantings. In addition, in subsequent plantings, $\mathrm{Pb}$ and $\mathrm{Cr}$ gradually changed from the residual fraction to the potentially effective and aceticacid-extractable fractions in coalash-amended soil (Bai et al., 2019). Therefore, the bioavailability of $\mathrm{Pb}$ and Crimproved continuously and the pakchoi absorbed and used more $\mathrm{Pb}$ and $\mathrm{Cr}$, which could affect the quality of pakchoi and lead to potential food safety issues.

\section{PH of Coal-Ash-Amended Soil}

The bioavailability of $\mathrm{Cu}$ and $\mathrm{Zn}$ in soil is negatively correlated with soil $\mathrm{pH}$ and that of $\mathrm{Pb}$ is significantly lower than that of total $\mathrm{Pb}$ under alkaline conditions (Bhogal et al., 1993; Bose and Bhattacharyya, 2008). The $\mathrm{pH}$ of dry ash is greater than 11.0, while that of wet ash ranges from 7.7 to 8.7 (Pandey and Singh, 2020; Singh et al., 2008; Wu et al., 1995). As shown in Fig. 2, before planting pakchoi, the $\mathrm{pH}$ of the coal-ash-amended soil increased significantly, because alkaline matter in the coal ash reacted with acidic components in the soil (Matsi and Keramidas, 1999). The pH also increased with the coalash application rate. The influence of fly ash on soil $\mathrm{pH}$ was greater than that of bottom ash.

With subsequent plantings of pakchoi, the $\mathrm{pH}$ of the CK increased slightly, while that of the soil treated with coal-ash decreased after four pakchoi plantings. This may have been due to the neutralization of organic acids released from the pakchoi rhizosphere by alkaline substances in the soil due to coal-ash application. As most crops grow at neutral $\mathrm{pH}$ (6.5-7.0), coal ash should be treated before agricultural use or used to adjust the $\mathrm{pH}$ of acidified soil. 


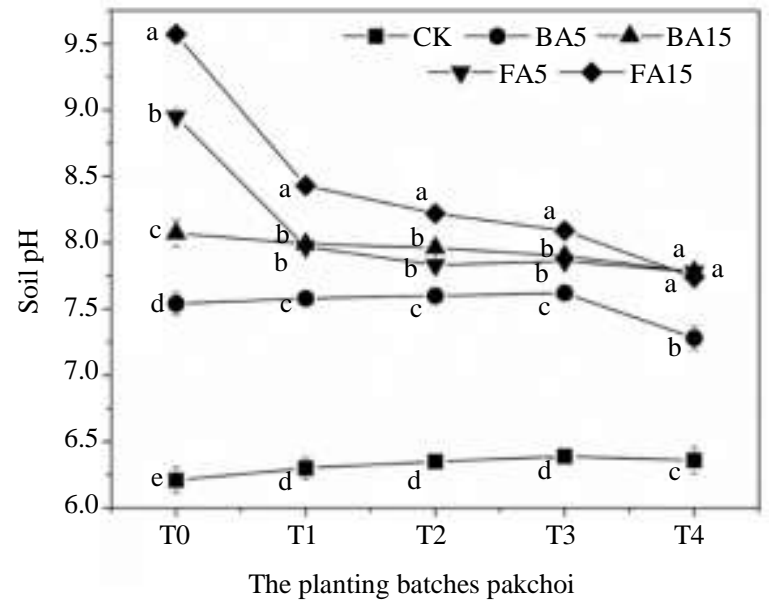

Fig. 2: Changes in soil $\mathrm{pH}$ with different coal ash treatments and pakchoi plantings

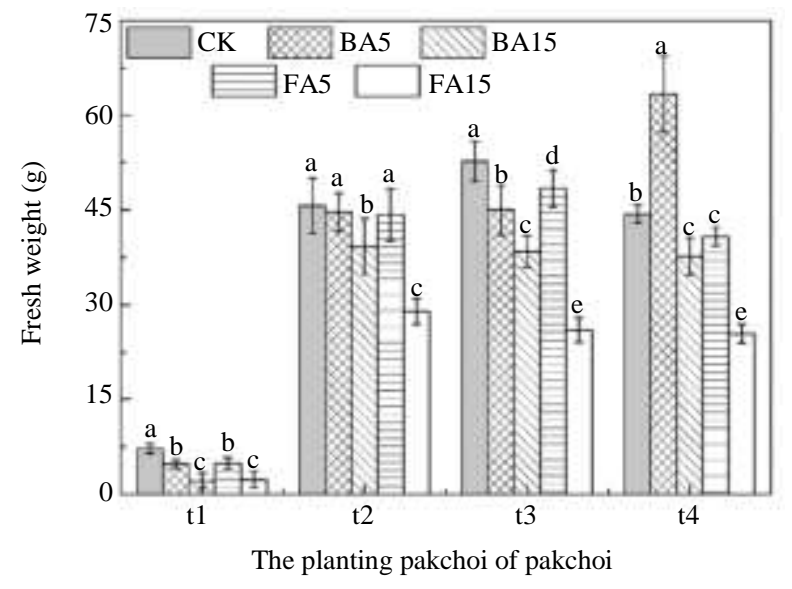

Fig. 3: Changes of fresh weight of pakchoi in different coal ash treatments and planting batches; Note: $\mathrm{t} 1$, the first batch of pakchoi; $\mathrm{t} 2$, the second batch of pakchoi; $\mathrm{t} 3$, the third batch of pakchoi; $\mathrm{t} 4$, the fourth batch of pakchoi. The same meanings are as follows

\section{Fresh Weight of Pakchoi Grown in the Coal-Ash- Amended Soil}

The fresh weights of pakchoi planted in BA15 and FA15 were lower than that of pakchoi planted in CK (Fig. 3), implying that the biomass of pakchoi was related to the amount of coal ash applied, which has been proved in rice, spinach, mung bean and other plants (Mittra et al., 2005; Singh and Agrawal, 2010; Sinha et al., 2007). It was because fly ash contains only traces of nitrogen and organic matter and a high application rate of fly ash dilutes the amounts present in soil, while increasing the heavy-metal contents (Nayak et al., 2015). Application of coal ash also changes the physicochemical properties of soil and the leached heavy metals and adverse growth environment inhibit the growth of crops (Gupta et al., 2002; Pandey and Singh, 2020). When the pH of soil was higher with high coal-ash application (Fig. 2), pakchoi becomes stressed and grows poorly.

\section{Heavy-Metal Contents of Pakchoi}

For the same coal-ash content, the total $\mathrm{Pb}$ content of the shoots and roots was greater in bottom-ashamended soil than in fly-ash-amended soil (Fig. 4). With subsequent plantings, however, the total $\mathrm{Pb}$ content of pakchoi grown in the coal-ash-amended soil increased gradually, but not significantly, in the CK. It was also founded that the metal accumulation in ground organs and shoots of Scirpus littoralis increased with time (Bhattacharya et al., 2006). The change in $\mathrm{Cr}$ in pakchoi was similar to that of $\mathrm{Pb}$, but the $\mathrm{Cr}$ content of pakchoi grown in $\mathrm{CK}$ was the lowest. With subsequent plantings, the acetic-acid-soluble concentrations of $\mathrm{Pb}$ and $\mathrm{Cr}$ in coal-ash-amended soil increased gradually and the $\mathrm{Pb}$ and $\mathrm{Cr}$ contents of pakchoi also increased, indicating that the bioavailability of $\mathrm{Pb}$ and $\mathrm{Cr}$ in coalash-amended soil increased continuously. Considering the background levels of $\mathrm{Pb}$ and $\mathrm{Cr}$ in the $\mathrm{CK}$, this increasing trend might lead to $\mathrm{Pb}$ and $\mathrm{Cr}$ pollution in the soil and toxic levels in pakchoi. Besides, $\mathrm{Pb}$ and $\mathrm{Cr}$ concentrations were higher in shoots than in roots, which was similar to the concentration in the mung bean but was opposite to the concentration in Trifolium repens (Lopareva-Pohu et al., 2011b; Singh and Agrawal, 2010).

The total $\mathrm{Cu}$ content of pakchoi decreased with subsequent plantings. The $\mathrm{Cu}$ content was higher in shoots than in roots for all treatments, implying that in pakchoi $\mathrm{Cu}$ is transferred from the roots to the shoots. A cowpea (Vigna unguiculata) experiment had similar results and the $\mathrm{Cr}$ and $\mathrm{Cu}$ contents were higher in cowpea shoots than in roots (Chaudhary et al., 2011). In our experiment, the $\mathrm{Zn}$ content was lower in pakchoi shoots than in roots, while the opposite was seen for cowpea, which might be attributed to differences in nutrient absorption by different crops. With subsequent plantings, the $\mathrm{Zn}$ content of pakchoi shoots increased in all ash treatments and was higher in the coal-ash-amended soil than in the CK for all plantings. Because of the low solubility of $\mathrm{Zn}$ compounds, the absorption of $\mathrm{Zn}$ by negatively charged colloidal soil particles increases and the availability of $\mathrm{Zn}$ decreases with increasing $\mathrm{pH}$ (Maiti and Jaiswal, 2008). The total $\mathrm{Zn}$ content was higher in pakchoi grown in the CK than in the coal-ash-amended soil (Fig. 4), indicating that the availability of $\mathrm{Zn}$ was lower in the coal-ash-amended soil. 

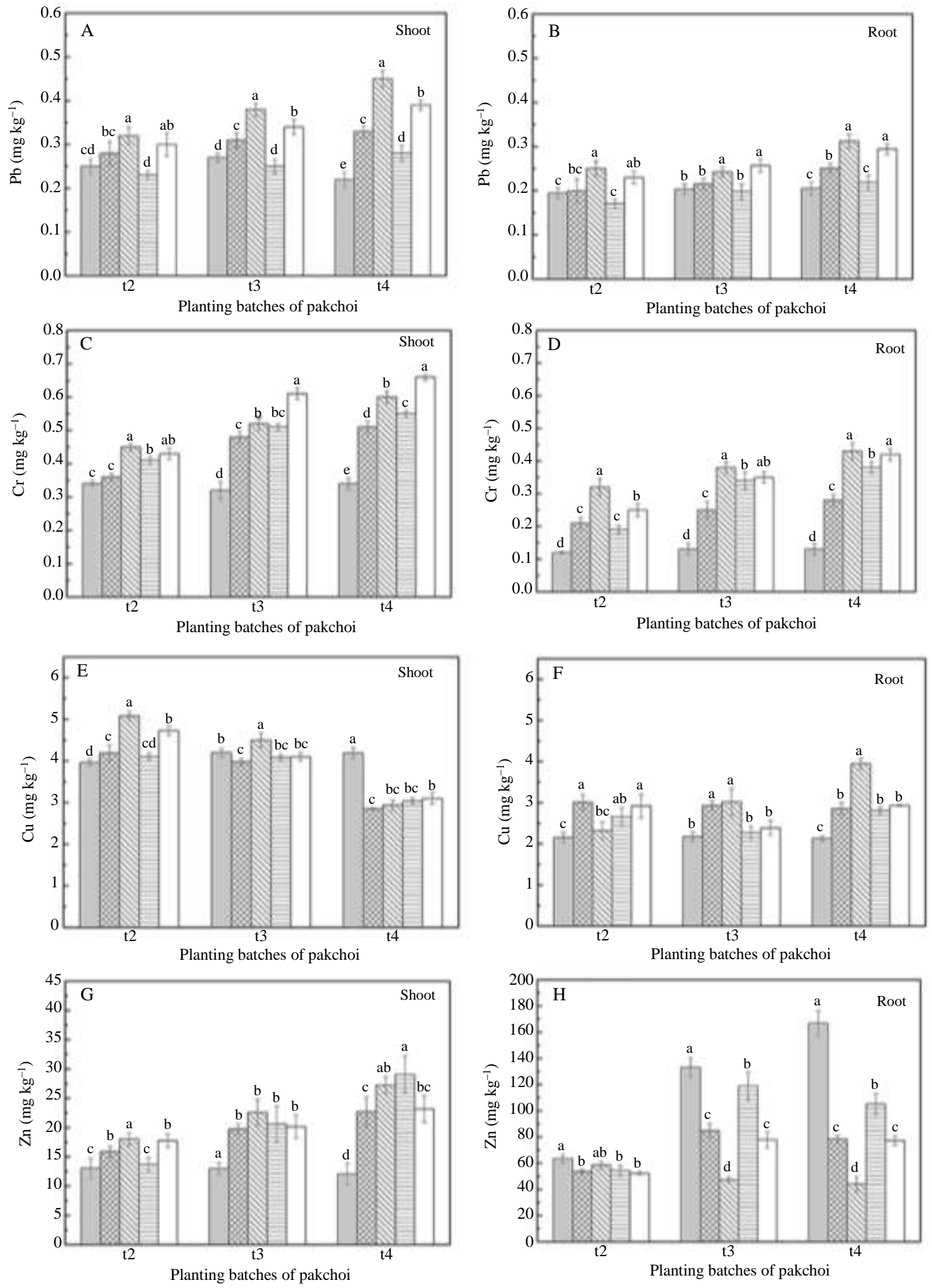

CK

BA15

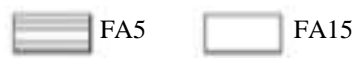

Fig. 4: The metal contents of the roots and shoots of pakchoi according to the coal-ash treatment and pakchoi planting 


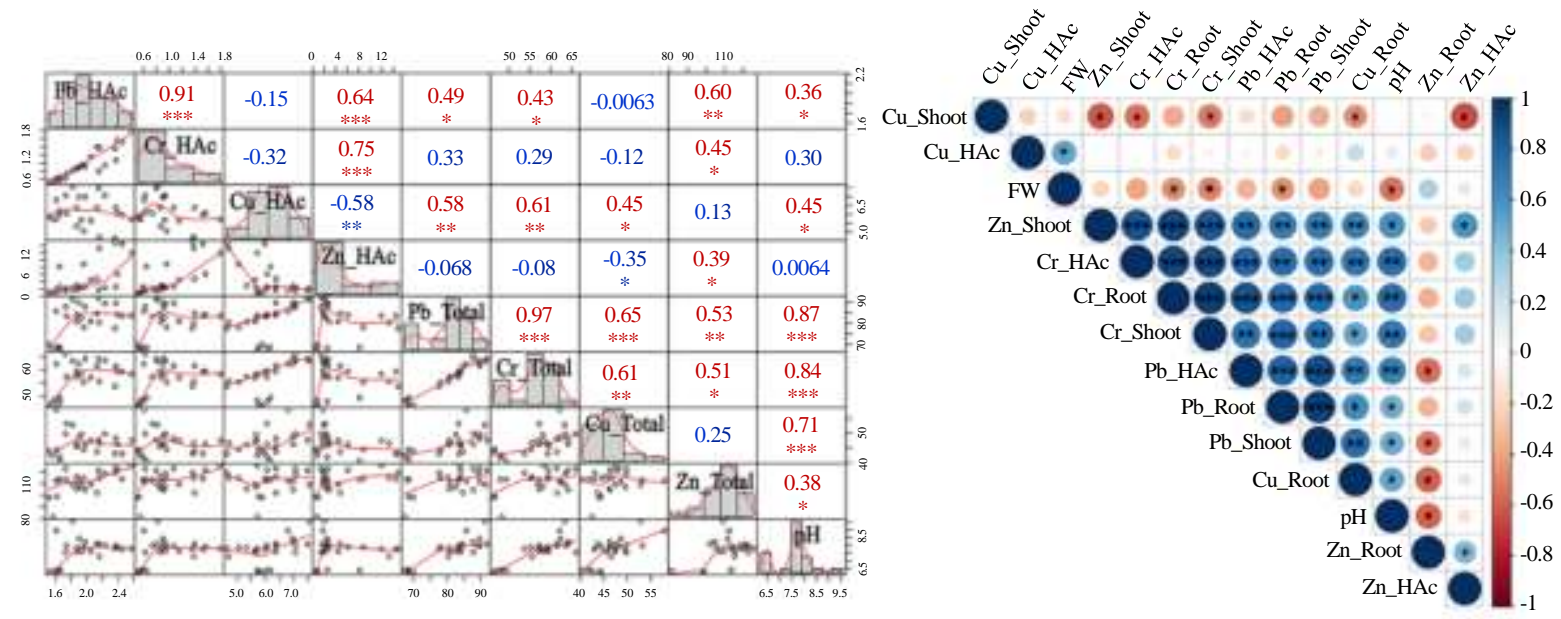

Fig. 5: Pearson's correlation of the heavy-metal contents of the experimental soils and soil $\mathrm{pH}$ (A). Pearson's correlation of the heavymetal contents in the roots and shoots of pakchoi and in the soil, $\mathrm{pH}$ and fresh weight of pakchoi (B); Note: $\mathrm{Pb} \_\mathrm{Total}, \mathrm{Pb} \_\mathrm{HAc}$, $\mathrm{Pb} \_$Shoot and $\mathrm{Pb} \_$Root represented the total contents of $\mathrm{Pb}$ in the soils, the acetic-acid-extractable content of $\mathrm{Pb}$ in the soils, the $\mathrm{Pb}$ content in the shoots and the $\mathrm{Pb}$ content in the roots of pakchoi, respectively. The representation of other elements was similar. $\mathrm{pH}$ and $\mathrm{FW}$ represented the $\mathrm{pH}$ value of soils and fresh weight of pakchoi. The significance is indicated: $* P<0.05 ; * *$ $P<0.01$; *** $P<0.001$

\section{Correlation Among Heavy-Metal Content, Pakchoi Biomass and Soil $\mathrm{pH}$}

From the Fig. 5A, there was a significant positive correlation between total contents of $\mathrm{Pb}$ and $\mathrm{Cr}$ in the soils $(\mathrm{r}=0.97, P<0.001)$ and between acetic-acid-extractable contents of $\mathrm{Pb}$ and $\mathrm{Cr}(\mathrm{r}=0.91, P<0.001)$, which indicated that they changed similarly between treatments. It was obvious that there were significantly positive correlations between the total content of $\mathrm{Pb}, \mathrm{Cr}, \mathrm{Cu}$, or $\mathrm{Zn}$ and $\mathrm{pH}$ in the soils $(P<0.05)$ (Fig. 5A), these phenomena also occurred in previous published researches (Chen et al., 2011; Li et al., 2009). The exchangeable heavy-metal content of soil is negatively correlated with $\mathrm{pH}$, while the heavy-metal content of the carbonate-bound state is positively correlated with $\mathrm{pH}$ (Han et al., 2005) and the relationship between the carbonate-bound state and $\mathrm{pH}$ is stronger. In our experiment, there were positive correlations of the acetic-acid-extractable concentrations of $\mathrm{Pb}$ or $\mathrm{Cu}$ in the soils with $\mathrm{pH}$. Figure 1 and 2 show that the relationship between $\mathrm{pH}$ and the four heavy metals was consistent with the results of the correlation analysis. Therefore, $\mathrm{pH}$ is an important factor determining the concentrations of different heavy metals (Huang et al., 2012).

As showed in Fig. 5B, the $\mathrm{Pb}$ and $\mathrm{Cr}$ contents of shoots were positively correlated with the contents of roots, and the acetic-acid-extractable $\mathrm{Pb}$ and $\mathrm{Cr}$ contents of soil were positively correlated with those of the roots and shoots, respectively. Therefore, the rates of migration of $\mathrm{Pb}$ and $\mathrm{Cr}$ in the soil-pakchoi system were similar; the acetic acidextractable content of $\mathrm{Pb}$ and $\mathrm{Cr}$ in soil affect the content of pakchoi. While, the $\mathrm{Cu}$ and $\mathrm{Zn}$ contents of shoots were negatively correlated with the contents of roots and were positively correlated with the acetic-acid-extractable $\mathrm{Cu}$ and $\mathrm{Zn}$ contents of soil, with coefficients of 0.566 and 0.873 , respectively (all $P<0.05$ ). The $\mathrm{Pb}, \mathrm{Cu}$ or $\mathrm{Zn}$ contents in different organ of rice also showed obvious correlation (Zhou et al., 2014). Besides, the $\mathrm{Pb}, \mathrm{Cr}, \mathrm{Cu}$ and $\mathrm{Zn}$ contents in the roots and roots all hold negative correlation with the fresh weight of pakchoi.

\section{Environmental Risk Assessment of Coal-Ash- Amended Soil}

\section{Single-Factor Index $\left(P_{i}\right)$ and the Nemerow Pollution Index (NPI)}

Figure 6A shows that the average value of $P_{i}$ calculated according to the environmental quality standards (China, 2018) declined in the order $1>\mathrm{Cu}>$ $\mathrm{Pb}>\mathrm{Zn}>\mathrm{Cr}$, which means that all four elements in the soil tested were in the safe range. However, the average value of $P_{i}$ calculated according to the environmental protection vocation standards (China, 2006) declined in the order $\mathrm{Pb}>1>\mathrm{Cu}>\mathrm{Zn}>\mathrm{Cr}$. The $P_{i}$ of $\mathrm{Pb}$ in $\mathrm{CK}$ was greater than 1 , implying a low risk of $\mathrm{Pb}$ in the $\mathrm{CK}$. The $P_{i}$ of a specific metal was higher in CK than in coal-ash-amended soil. Soil $\mathrm{pH}$ increased with application of coal ash, which resulted in a limited change in the value of $S_{i}$ in the environmental quality standards (China, 2018). In subsequent plantings, the $P_{i}$ for $\mathrm{Cu}$ declined more significantly in fly-ashamended soil than in bottom-ash-amended soil. The $P_{i}$ for $\mathrm{Zn}$ was higher in bottom-ash-amended soil than in fly-ash-treated soil. 

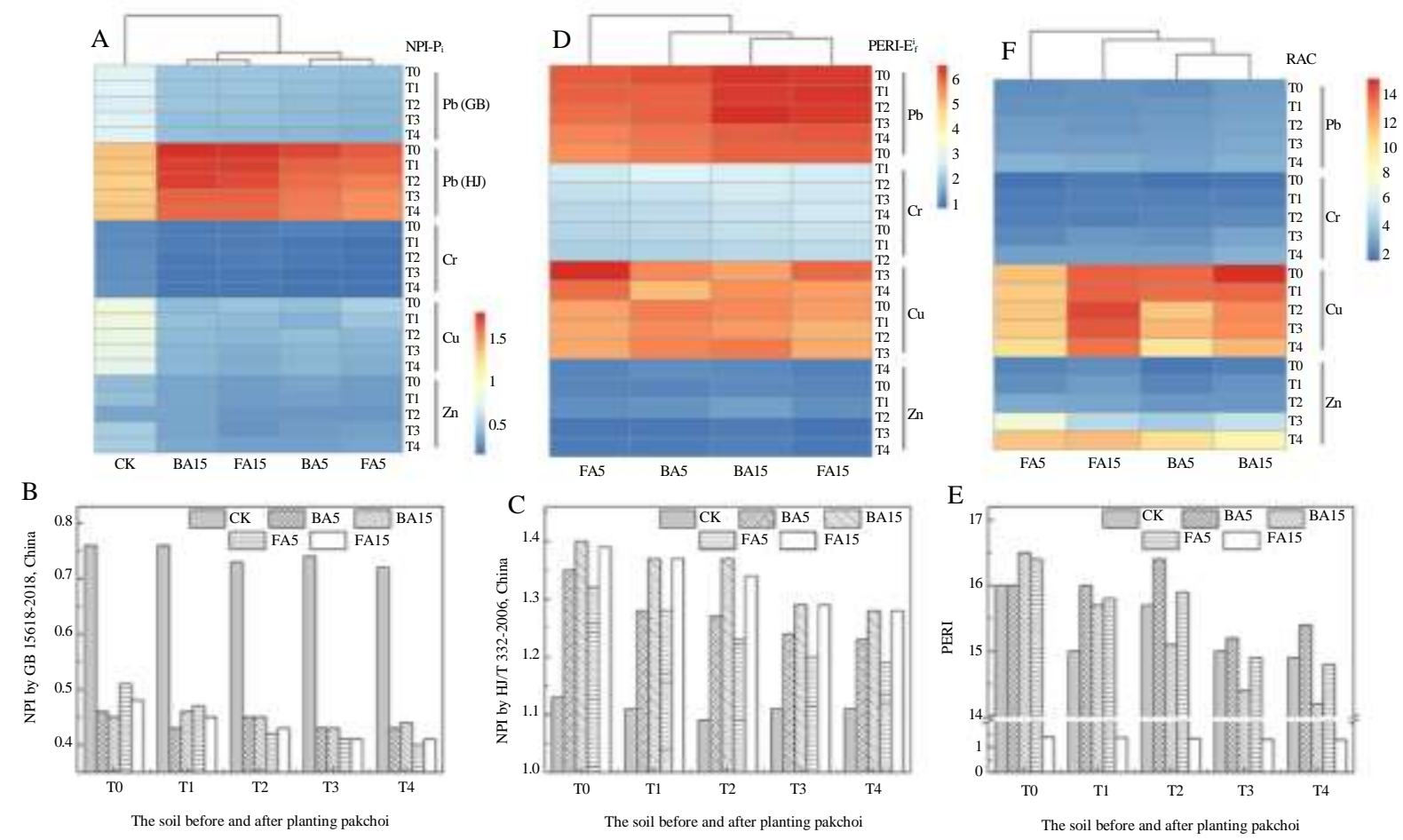

Fig. 6: Heatmap of Single-factor pollution index of heavy metals (NPI- $\left.P_{i}\right)(\mathrm{A})$, potential ecological risk index of a given metal (PERI$\left.E_{f}^{i}\right)(\mathrm{D})$ and risk assessment code (RAC) (F) in coal-ash-amended soil; Nemerow pollution index (NPI) (B and C) and potential ecologicalrisk index (PERI) (E) of the four metals in coal-ash-amended soil; Note: the GB 15618-2018, China (GB) and HJ/T 332-2006, China (HJ) provided the different $S_{i}$ values of Pb to calculate the NPI- $P_{i}$ and NPI, while the $S_{i}$ values of $\mathrm{Cr}, \mathrm{Cu}$ and $\mathrm{Zn}$ are the same as in the two standards

In China, the excess multiples of $\mathrm{Pb}, \mathrm{Cr}, \mathrm{Cu}$ and $\mathrm{Zn}$ in sewage irrigation in 1980-2010 were 7.5, 2.4, 4.1-8.2 and 5.3, respectively (Xin et al., 2011). The $\mathrm{As}, \mathrm{Hg}, \mathrm{Pb}, \mathrm{Cd}$, $\mathrm{Cr}$ and $\mathrm{Ni}$ from atmospheric deposition account for $35-85 \%$ of that in farmland (Luo et al., 2009). At the same time, the absorption of heavy metals by vegetables comes not only from the contaminated soil, but also from atmospheric deposition (Feng et al., 2018). Therefore, the background value of agricultural soil should be considered before applying coal ash, to prevent superimposed pollution. The NPI calculated using the relatively strict environmental protection standard was greater than 1 and the risk was moderate (Fig. 6B and 6C).

\section{Potential Ecological Risk Index (PERI)}

The $E_{f}^{i}$ of specific metals in all samples was in the order $40>\mathrm{Pb}>\mathrm{Cu}>\mathrm{Cr}>\mathrm{Zn}$ (Fig. 6D), indicating that $\mathrm{Pb}$ carries more potential risk than the other three elements. The $E_{f}^{i}$ of $\mathrm{Pb}$ and $\mathrm{Cr}$ decreased in subsequent plantings. The PERI of the four metals was $<1$, indicating low risk. The average PERI of the four metals decreased in the order BA5 > FA5, BA15 > FA15 (Fig. 6E). Therefore, fly ash is more environmentally friendly than bottom ash.

\section{Risk Assessment Code (RAC)}

$\mathrm{Pb}$ and $\mathrm{Cr}$ were low risk based on RAC and the RAC of $\mathrm{Pb}$ and $\mathrm{Cr}$ increased in subsequent plantings (Fig. 6F). The acetic-acid-extractable fractions of $\mathrm{Pb}$ and $\mathrm{Cr}$ increased and the residual fraction decreased, which increased the extractable content and bioavailability of $\mathrm{Pb}$ and $\mathrm{Cr}$, indicating that both have strong releasing ability. The RAC of $\mathrm{Pb}$ and $\mathrm{Cr}$ in all treatments was in the order BA15 > FA15 > BA5 > FA5, indicating that the bottom ash releases more $\mathrm{Pb}$ and $\mathrm{Cr}$ than fly ash. Based on the RAC, the $\mathrm{Cu}$ in coal-ash-amended soil was classified as moderate risk. The researches have also showed that the organic acids secreted by the roots of crops could dissolve the carbonate and oxidized heavy metals, increasing the most effective heavy metals in the soluble and exchangeable fraction (Mench and Fargues, 1994; Mo et al., 2002). With subsequent plantings, the $\mathrm{RAC}$ of $\mathrm{Cu}$ in BA5 decreased from 14.17 to $8.03 \%$ and the pollution risk decreased from medium to low. After the fourth planting of pakchoi, the level of $\mathrm{Cu}$ pollution was still moderate. Compared with the other three elements, $\mathrm{Cu}$ seems to be more easier to be dissolved out, which makes the RAC value larger and the potential risk stronger (Zhou et al., 2013). The RAC of $\mathrm{Zn}$ 
increased sharply, especially in FA15. Except BA15, the $\mathrm{RAC}$ of $\mathrm{Zn}$ increased from low to moderate risk.

Therefore, although there is huge output of coal ash at present and many researches focused on its effective utilization (Hao et al., 2012; Patra et al., 2012; Sarkar et al., 2017). Coal ash, whether as fertilizer additive or soil improvement material, has the environmental pollution risk, according to our results. However, coal ash, as a kind of hydrophobic, water and fertilizer retention agent with good physical and chemical properties (Pandey and Singh, 2020), could be applied to nonagricultural fields such as landscaping but should be forbidden to use near farmland, so as to cause the agricultural pollution by surface runoff.

\section{Comparison of the Three Risk Assessments}

The results differed by evaluation method. $P_{i}$ and NPI adopt relevant national standards as evaluation limits, where use of different standards will lead to different results. The $P_{i}$ and NPI of the specific heavy metals calculated using the national soil environmental quality standards were in the clean level, while the $P_{i}$ and NPI of $\mathrm{Pb}$ calculated using the environmental protection standard indicated low and moderate risks, respectively, due to the stricter limits of the protection standards. The PERI usually takes the soil background value in a certain area as the evaluation limit, while we took the content of the $\mathrm{CK}$ as the background value to represent the pollution level of the coal-ash-amended soil. In addition, that PERI could describe both ecological risk caused by single pollutant and overall risk or contamination from varied pollutants (Yuan et al., 2015). The single-factor and composite indexes of specific heavy metals indicated that they are not a risk by PERI. However, the results only based on the total contents of heavy metals are not accurate. It is more practical to evaluate the heavy metal pollution combining with the heavy metal effective fraction which can more effectively reflect the bioavailability and heavy metal pollution (Chojnacka et al., 2005; Li et al., 2007).

The RAC uses the acetic-acid-extractable fraction as the effective part, calculates its ratio relative to the total and evaluates the risk of release of heavy metals into the soil (Zhang et al., 2017). Using this method to evaluate heavy-metal pollution would yield different results for different heavy metals and plantings of pakchoi. With subsequent plantings, the RACs of $\mathrm{Pb}$, $\mathrm{Cr}$ and $\mathrm{Zn}$ increased and $\mathrm{Zn}$ eventually reached a medium risk, while the RAC of $\mathrm{Cu}$ decreased. Therefore, the results from the two other risk assessment methods showed that the pollution assessment index of the four heavy metals decreased with subsequent pakchoi plantings, but the risk of metal availability increased gradually.

\section{Conclusion}

Coal-ash application had an adverse effect on pakchoi growth and biomass yield, especially application of $15 \%$ coal ash. With subsequent plantings, the aceticacid- extractable concentrations of $\mathrm{Pb}$ and $\mathrm{Cr}$ increased. The $\mathrm{Pb}, \mathrm{Cr}$ and $\mathrm{Cu}$ contents were higher in pakchoi grown in the coal-ash-amended soil than in the $\mathrm{CK}$ and the $\mathrm{Pb}$ and $\mathrm{Cr}$ contents gradually increased in subsequent plantings. The findings demonstrate that application of unmodified coal ash, including bottom and fly ash, will cause heavy-metal pollution in soil, improve the bioavailability of some metals and increase the heavymetal content of pakchoi. The pollution risk would increase with subsequent plantings.

\section{Acknowledgement}

This work was supported by the National Natural Science Foundation of China (No. 31972516); and the Major Research Project of ShandongProvince (Public Welfare Special) (No. 2017GNC11116).

\section{Author's Contributions}

Wenxuan Sun, Liyong Bai and Huihui Ji: Designed and performed the experiments, wrote original draftpreparation.

Dongyun Yan, Wentao Huo, Zhen Huang and Kezhong Liu: Revised the manuscript.

\section{Ethics}

The authors declare their responsibility for any ethical issues that may arise after the publication of this manuscript.

\section{Conflict of Interest}

The authors declare that they have no competing interests. The corresponding author affirms that all of the authors have read and approved the manuscript.

\section{References}

Ahmaruzzaman, M. (2010). A review on the utilization of fly ash. Progress in energy and combustion science, 36(3), 327-363. https://doi.org/10.1016/j.pecs.2009.11.003

Bai, L.Y., Ji, H. H., Sun, W. X., Huang, M. L., Liu, K. Z., Li, L. Y., \& Yan, D. Y. (2019). Morphological transformation and migration of heavy metals $(\mathrm{Pb}$, $\mathrm{Cr}$ and $\mathrm{Cu}$ ) in coal ash applied to the soil-chinese cabbage system. Acta Pedologica Sinica, 56, 682-692. https://doi.org/10.11766/trxb201807250344 
Bhattacharya, T., Banerjee, D. K., \& Gopal, B. (2006) Heavy metal uptake by Scirpus littoralis schrad. from fly ash dosed and metal spiked soils. Environmental monitoring and assessment, 121(1), 363-380. https://doi.org/10.1007/s10661-005-9133-1

Bhogal, N. S., Sakal, R., Singh, A. P., \& Sinha, R. B. (1993). Micronutrient status in Aquic Ustifluvents and Udifluvents as related to certain soil properties. Journal of the Indian Society of Soil Science, 41(1), 75-78. https://www.indianjournals.com/ijor.aspx?target=ij or:jisss $\&$ volume $=41 \&$ issue $=1 \&$ article $=016$

Bose, S., \& Bhattacharyya, A. K. (2008). Heavy metal accumulation in wheat plant grown in soil amended with industrial sludge. Chemosphere, $70(7)$, 1264-1272. https://doi.org/10.1016/j.chemosphere.2007.07.062

Chaudhary, S. K., Rai, U. N., Mishra, K., Huang, H. G., Yang, X. E., Inouhe, M., \& Gupta, D. K. (2011). Growth and metal accumulation potential of Vigna radiata L. grown under fly-ash amendments. Ecological Engineering, 37(10), 1583-1588. https://doi.org/10.1016/j.ecoleng.2011.04.004

Chen, L. H., Luo, X. H., \& Hasi, Q. M. G. (2011). Pollute situation and correlation analysis of soil heavy metals in oil field. Journal of North University of China (Natural Science Edition), 32, 189-194. https://en.cnki.com.cn/Article_en/CJFDTotalHBGG201102016.htm

China. (2018). Soil environmental quality Risk control standard for soil contamination of agricultural land. GB15618-2018.

http://www.mee.gov.cn/ywgz/fgbz/bz/bzwb/trhj/201 807/t20180703_446029.shtml

China. (2006). Farmland environmental quality evaluation standards for edible agricultural products. $\mathrm{HJ} / \mathrm{T}$ 332-2006.

http://datacenter.mee.gov.cn/websjzx/report!list.acti on? $\mathrm{xmlname}=1520238134405$

Chojnacka, K., Chojnacki, A., Gorecka, H., \& Górecki, H. (2005). Bioavailability of heavy metals from polluted soils to plants. Science of the total Environment, 337(1-3), 175-182. https://doi.org/10.1016/j.scitotenv.2004.06.009

El-Mogazi, D., Lisk, D. J., \& Weinstein, L. H. (1988). A review of physical chemical and biological properties of fly ash and effects on agricultural ecosystems. [Crops grown on landfill with soil cap]. Sci. Total Environ.; (Netherlands), 74. https://doi.org/10.1016/0048-9697(88)90127-1

Feng, S. P., Liu, S. T., Du, W., Guo, B., Zhao, X. F., \& Liu, H. B. (2009). Assessment of Cu, Zn, Fe, Mn Species in Different Soils by Modified BCR and Tessier Extraction Procedures. Journal of Instrumental Analysis, 3, 297-300. https://en.cnki.com.cn/Article_en/CJFDTotalTEST200903011.htm
Feng, Y., Ma, L. Y., Wang, Q., Wu, Y. J., \& Huang, L. K. (2018). Heavy-metal pollution and safety production technologies of soil-vegetable crop systems in China. Journal of Agro-Environmental Science, 37, 2359-2370. https://doi.org/10.11654/jaes.2018-0787

Gupta, D. K., Rai, U. N., Tripathi, R. D., \& Inouhe, M. (2002). Impacts of fly-ash on soil and plant responses. Journal of Plant Research, 115(6), 401-409. https://doi.org/10.1007/s10265-002-0057-3

Han, C., Wang, L., Gong, Z., \& XU, H. (2005). Chemical forms of soil heavy metals and their environmental significance. Chinese Journal of Ecology, (12), 1499.

Hao, Q., Hai-Hong, G. U., Er-Kai, H. E., Shi-Zhong, W. A. N. G., \& Rong-Liang, Q. I. U. (2012). Attenuation of metal bioavailability in acidic multimetal contaminated soil treated with fly ash and steel slag. Pedosphere, 22(4), 544-553. https://doi.org/10.1016/S1002-0160(12)60039-3

Huang, X. X., Zhu, X. F., Tang, L., \& Ji, H. (2012). Pollution characteristics and their comparative study of heavy metals in the gold and iron mine soil of the upstream area of Miyun Reservoir, Beijing. Acta Scientiae Circumstantiae, 32(6), 1520-1528.

Jala, S., \& Goyal, D. (2006). Fly ash as a soil ameliorant for improving crop production-a review. Bioresource technology, 97(9), 1136-1147. https://doi.org/10.1016/j.biortech.2004.09.004

Ke, X., Gui, S., Huang, H., Zhang, H., Wang, C., \& Guo, W. (2017). Ecological risk assessment and source identification for heavy metals in surface sediment from the Liaohe River protected area, China. Chemosphere, 175, 473-481. https://doi.org/10.1016/j.chemosphere.2017.02.029

Li, F., Li, X., Wu, P., Chen, L. Y., Guo, B., \& Qi, Z. P. (2009). Correlation between heavy metal pollution and basic properties of agricultural soils in Hainan province. $\quad$ Soils, 41(1), 49-53. https://en.cnki.com.cn/Article_en/CJFDTotalTURA200901010.htm

Li, J. X., Yang, X. E., He, Z. L., Jilani, G., Sun, C. Y., \& Chen, S. M. (2007). Fractionation of lead in paddy soils and its bioavailability to rice plants. Geoderma, 141(3-4), 174-180. https://doi.org/10.1016/j.geoderma.2007.05.006

Li, L. L., \& Jiang, Z. Q. (1998). Physicochemical features and comprehensive utilization on fly-ash. Research of Environmental Sciences, 11(3), 60-62. https://doi.org/10.13198/j.res.1998.03.65.lil.015

Lopareva-Pohu, A., Verdin, A., Garçon, G., Sahraoui, A. L. H., Pourrut, B., Debiane, D., ... \& Shirali, P. (2011a). Influence of fly ash aided phytostabilisation of $\mathrm{Pb}, \mathrm{Cd}$ and $\mathrm{Zn}$ highly contaminated soils on Lolium perenne and Trifolium repens metal transfer and physiological stress. Environmental Pollution, 159(6), 1721-1729. https://doi.org/10.1016/j.envpol.2011.02.030 
Lopareva-Pohu, A., Pourrut, B., Waterlot, C., Garçon, G., Bidar, G., Pruvot, C., ... \& Douay, F. (2011b). Assessment of fly ash-aided phytostabilisation of highly contaminated soils after an 8-year field trial: part 1. Influence on soil parameters and metal extractability. Science of the total environment, 409(3), 647-654. https://doi.org/10.1016/j.scitotenv.2010.10.040

Luo, L., Ma, Y., Zhang, S., Wei, D., \& Zhu, Y. G. (2009). An inventory of trace element inputs to agricultural soils in China. Journal of Environmental Management, 90(8), 2524-2530. https://doi.org/10.1016/j.jenvman.2009.01.011

Maiti, S. K., \& Jaiswal, S. (2008). Bioaccumulation and translocation of metals in the natural vegetation growing on fly ash lagoons: a field study from Santaldih thermal power plant, West Bengal, India. Environmental monitoring and assessment, 136(1), 355-370. https://doi.org/10.1007/s10661-007-9691-5

Matsi, T., \& Keramidas, V. Z. (1999). Fly ash application on two acid soils and its effect on soil salinity, $\mathrm{pH}$, $\mathrm{B}, \mathrm{P}$ and on ryegrass growth and composition. Environmental Pollution, 104(1), 107-112. https://doi.org/10.1016/S0269-7491(98)00145-6

Mench, M. J., \& Fargues, S. (1994). Metal uptake by ironefficient and inefficient oats. Plant and soil, 165(2), 227-233. https://doi.org/10.1007/BF00008066

Mittra, B. N., Karmakar, S., Swain, D. K., \& Ghosh, B. C. (2005). Fly ash-a potential source of soil amendment and a component of integrated plant nutrient supply system. Fuel, 84(11), 1447-1451. https://doi.org/10.1016/j.fuel.2004.10.019

Mo, Z., Wang, C. X., Chen, Q., \& Wang, Z. (2002). Form distribution and transformation of heavy metals of $\mathrm{Cu}, \mathrm{Pb}, \mathrm{Zn}, \mathrm{Cr}$ and $\mathrm{Cd}$ in soils. Agro-environmental Protection, 21(1), 9-12.

Mukhtar, S., Kenimer, A. L., Sadaka, S. S., \& Mathis, J. G. (2003). Evaluation of bottom ash and composted manure blends as a soil amendment material. Bioresource Technology, 89(3), 217-228. https://doi.org/10.1016/S0960-8524(03)00085-3

Nayak, A. K., Raja, R., Rao, K. S., Shukla, A. K., Mohanty, S., Shahid, M., ... \& Swain, C. K. (2015). Effect of fly ash application on soil microbial response and heavy metal accumulation in soil and rice plant. Ecotoxicology and environmental safety, 114 , 257-262 https://doi.org/10.1016/j.ecoenv.2014.03.033

Okalebo, J. R., Gathua, K. W., \& Woomer, P. L. (2002). Laboratory methods of soil and plant analysis: a working manual second edition. Sacred Africa, Nairobi, 21 file://C:/Users/user/Downloads/SoilAnalysesmanu al\%20(2).pdf
Pandey, V. C., \& Singh, N. (2010). Impact of fly ash incorporation in soil systems. Agriculture, ecosystems \& environment, 136(1-2), 16-27. https://doi.org/10.1016/j.agee.2009.11.013

Patra, K. C., Rautray, T. R., \& Nayak, P. J. A. R. (2012). Analysis of grains grown on fly ash treated soils. Applied Radiation and Isotopes, 70(8), 1797-1802. https://doi.org/10.1016/j.apradiso.2012.03.037

Phung, H. T., Lam, H. V., Page, A. L., \& Lund, L. J. (1979). The practice of leaching boron and soluble salts from fly ash-amended soils. Water, Air and Soil Pollution, 12(2), 247-254. https://doi.org/10.1007/BF01047127

Qunhu, X., Yuan, Y., \& Guangliang, Y. (2008). Research on the Physical, Chemical Properties and Morphology of Fly Ash. Fly Ash Comprehensive Utilization, 3, 3-5. https://en.cnki.com.cn/Article_en/CJFDTotalFMLE200803002.htm

Sarkar, S. R., Majumdar, A., Barla, A., Pradhan, N., Singh, S., Ojha, N., \& Bose, S. (2017). A conjugative study of Typha latifolia for expunge of phyto-available heavy metals in fly ash ameliorated soil. Geoderma, 305, 354-362. https://doi.org/10.1016/j.geoderma.2017.06.022

Shi, Y. L., Qiu, G. Z., \& Chen, C. (2003). Discussion on applications of bottom ash. Fly Ash Comprehensive Utilization, 6 , 47-48. https://doi.org/10.3969/j.issn.10058249.2003.06.021

Siddiqui, S., Ahmad, A., \& Hayat, S. (2004). The fly ash influenced the heavy metal status of the soil and the seeds of sunflower. A case study. Journal of environmental biology, 25(1), 59-63. https://europepmc.org/article/med/15303705

Singh, A., \& Agrawal, S. B. (2010). Response of mung bean cultivars to fly ash: growth and yield. Ecotoxicology and Environmental Safety, 73(8), 1950-1958. https://doi.org/10.1016/j.ecoenv.2010.07.023

Singh, A., Sharma, R. K., \& Agrawal, S. B. (2008). Effects of fly ash incorporation on heavy metal accumulation, growth and yield responses of Beta vulgaris plants. Bioresource Technology, 99(15), 7200-7207. https://doi.org/10.1016/j.biortech.2007.12.064

Sinha, S., Mallick, S., Misra, R. K., Singh, S., Basant, A., \& Gupta, A. K. (2007). Uptake and translocation of metals in Spinacia oleracea L. grown on tannery sludge-amended and contaminated soils: effect on lipid peroxidation, morpho-anatomical changes and antioxidants. Chemosphere, 67(1), 176-187. https://doi.org/10.1016/j.chemosphere.2006.08.026

Song, J. X., Zhu, Q., Jiang, X. S., Zhao, H. Y., Liang, Y. H., Luo, Y. X., ... \& Zhao, L. L. (2017). GIS-based heavy metals risk assessment of agricultural soils-A case study of Baguazhou, Nanjing. Acta Pedofil. Sin, 54, 81-91. 
Sundaray, S. K., Nayak, B. B., Lin, S., \& Bhatta, D. (2011). Geochemical speciation and risk assessment of heavy metals in the river estuarine sediments-A case study: Mahanadi basin, India. J. Hazard Mater., 186:

1837-1846. https://doi.org/10.1016/j.jhazmat.2010.12.081

Wu, J., Liu, B., Dong, Y., Liu, J., \& Wang, G. (1995). Study on effect of soil amelioration with coal ash. Acta Pedologica Sinica, 32, 340-347.

Xin, S., Li, H., \& Su, D. (2011). Concentration characteristics and historical changes of heavy metals in irrigation sewage in China. Journal of Agro-Environment Science, 30(11), 2271-2278. https://www.cabdirect.org/cabdirect/abstract/20123 326129

Yuan, X., Leng, L., Huang, H., Chen, X., Wang, H., Xiao, Z., ... \& Zeng, G. (2015). Speciation and environmental risk assessment of heavy metal in bio-oil from liquefaction/pyrolysis of sewage sludge. Chemosphere, 120, 645-652. https://doi.org/10.1016/j.chemosphere.2014.10.010

Zhang, H., Luo, Y., Zhao, Q., Zhang, G., \& Wong, M. (2010). Hong Kong soil researches. VII. Research on fractions of heavy metals and their potential environmental risks in soil based on BCR sequential extraction. Acta Pedologica Sinica, 47(5), 865-871. https://www.cabdirect.org/cabdirect/abstract/201 13076160
Zhang, H., Liu, Y., Hou, L., Wang, Y., \& Qi, D. (2017). Pollution characteristics and ecological risk assessment of heavy metals in sediments of a typical outbound river ecological restoration area. Research of Environmental Sciences, 30(9), 1415-1424. https://www.cabdirect.org/cabdirect/abstract/20203 084030

Zhou, H., Zhou, X., Zeng, M., Liao, B. H., Liu, L., Yang, W. T., ... \& Wang, Y. J. (2014). Effects of combined amendments on heavy metal accumulation in rice (Oryza sativa L.) planted on contaminated paddy soil. Ecotoxicology and Environmental Safety, 101, 226-232. https://doi.org/10.1016/j.ecoenv.2014.01.001

Zhou, Y., Ning, X. A., Liao, X., Lin, M., Liu, J., \& Wang, J. (2013). Characterization and environmental risk assessment of heavy metals found in fly ashes from waste filter bags obtained from a Chinese steel plant. Ecotoxicology and environmental safety, 95, 130-136. https://doi.org/10.1016/j.ecoenv.2013.05.026 